\title{
Basic Technology Competencies, Attitude towards Computer Assisted Education and Usage of Technologies in Turkish Lesson: A Correlation
}

\author{
Serpil Özdemir ${ }^{1}$ \\ ${ }^{1}$ Department of Turkish Education, Education Faculty, Bartin University, Bartin,Turkey \\ Correspondence: Serpil Özdemir, Education Faculty, Bartin University, Bartin, Turkey. Tel: 90-532-470-4271. \\ E-mail: serpilozdemir34@gmail.com
}

Received: October 12, 2016

Accepted: November 16, 2016

Online Published: March 30, 2017

doi:10.5539/ies.v10n4p160

URL: https://doi.org/10.5539/ies.v10n4p160

\begin{abstract}
The present research was done to determine the basic technology competency of Turkish teachers, their attitude towards computer-assisted education, and their technology operation level in Turkish lessons, and to designate the relationship between them. 85 Turkish teachers studying in public schools in Bartin participated in the research. The research was designed with relational screening model. The results obtained in the research are as follows: The information technology competency of Turkish teachers was determined as high-level in technologies usually used vocationally, and as mid-level in others The Turkish teachers had high-level of attitude towards computer-assisted teaching. However, they tended to use technology in their lessons at mid-level. The dependent variables did not indicate remarkable differences based on gender, teaching experience, and education level. Results showed that there was a high-level relationship between the attitude towards computer-assisted education and using information technology in Turkish lessons. Also, there existed a mid-level relationship between the basic technology competency and attitude towards computer-assisted education.
\end{abstract}

Keywords: Turkish teachers, education technologies, competency, attitude, technology integration

\section{Introduction}

\subsection{Introduce the Problem}

In today's conditions where societies have changed from industrial to information and where knowledge has become one of the most important values, education has not remained far from this change.

The universities that train teachers have been making great effort to train teachers that are capable of using information technologies and transferring this capability to the teaching environment. The Ministry of National Education has also taken an important step with the "Movement of Enhancing Opportunities and Improving Technology" known as FATIH Project and has made investments in the educational use of information technologies. In the Tenth Development Plan, the main objectives of the education system were stated in the way that individuals using and producing science and technology should be trained and they should be brought up by attaining basic knowledge and skills. In the policy explained considering the realization of them, it has been stated that a transformation program involving a curriculum which has integrated into information and science technologies is going to be applied (The Ministry of Development, 2013, pp. 31-32).

The benefits of using information technologies in the educational environment could be expressed by making the lessons more attractive to students, making it easier to reach goals, avoiding wasting time and making learning more permanent (Katranc1 \& Uygun, 2013, p. 773).

Experimental studies indicate that computer-assisted Turkish lessons increase success and encourage the positive attitude towards Turkish lessons (Arslan, 2008; Durukan, 2011; Oval1, 2011; Zobar, 2010). In this respect, it is essential that teachersare capable of using information technologies. Thus, research indicate that the teachers who lack the necessary knowledge and skills do not use information and communication technologies (Buabeng-Andoh, 2012; Erdoğan, 2007; Flowers \& Algozzine, 2000; Gegeoğlu, 2014; Koçak-Usluel, Kuşkaya-Mumcu, \& Demiraslan 2007, Peralta \& Costa 2007).

The most important decisive in the use of information technologies in the educational environment is teachers' information and communication technologies competency (Buabeng-Andoh, 2012, 139). It is necessary for teachers to use information technologies; however, this is not adequate; it is also important for teachers to 
transfer these skills into the educational environment. Among the Special Area Competency of Turkish Teachers which have been put into effect by the approval 1385 by Board of Education on 04/06/2008 are stated as the skills that the teachers are expected to possess regarding the use of technological sources, to know the importance of the technological sources to make learning more effective, to know the sites and the software to reach knowledge, to evaluate the technological sources and to use them systematically to support teaching Turkish, to prepare the suitable conditions to enable students to benefit from the technological sources, to provide opportunities to students to criticize and to use appropriately the technological sources in learning Turkish (MEB Committee, 2008, p. 47).

It is important for teachers to have a positive attitude towards computer assisted education to get away from traditional teaching and to transfer information technologies to the educational environment. The positive attitude towards using information technologies in education is seen as an important factor to determine the use of technology in lessons (Christensen, 2002). Allport (1935) defined attitude as "a mental and neural state of readiness, organized through experience, exerting a directive and dynamic influence upon the individual's response to all objects and situations with which it is related" (p. 810). Using educational technologies in school curriculum depends on the attitudes of teachers (Buabeng-Andoh, 2012, p. 138). As their competency level increases, the attitude towards using technology in lessons increases (Lau \& Sim, 2008, p. 32).

\subsection{The Objective of the Research}

To enable teachers' to use information technologies effectively during education was one of the strategical targets of The Ministry of National Education between 2010 and 2014. Within the frame of this aim, there were big investments in equipping schools with information technologies. Teachers were given in-service training to use them. The beginning point of this research was to find out at what level was the relationship of Turkish teachers with information technologies after the investments and the training provided. The objective of the research was to determine Turkish teachers' basic technology competency, their attitudes towards computer-assisted education, their level of using information technology in Turkish lessons and the relationship between them.

\subsection{The Importance of the Research}

In the literature, it is seen that the research related to teaching Turkish and technology focus on prospective teachers (Atlı et al., 2007; Dargut \& Çelik, 2014; Eyüp, 2012; Özbay \& Çelik, 2013; Şahin \& Akçay, 2011). Turkish teachers' technology operation levels (Karasakaloğlu, Saracaloğlu, \& Uça, 2011) and their attitude towards computer assisted teaching (Kahraman, 2013) have been examined separately in various research, and there have been necessities to determine Turkish teachers' technology operation level in lessons.

This research reveals a holistic approach as it has been considered Turkish teachers' basic technology competency, their attitude towards computer assisted education, their technology operation level in Turkish lessons on the same sample. The research fulfills a gap as it considers the issue in a versatile way.

The most important role in the realization of the targets in education is the teachers'. It is important for them to be able to use technology and transfer this skill to teaching activities in front of today's children who can use technology quite well. In this context, the findings of this research are expected to be leading considering the developments and drawbacks are seen at teacher's level while providing the integration of technology in Turkish lessons and estimating the precautions that will be taken.

\subsection{The Problem Sentence and Sub-Problems}

The problem sentence of the research has been determined as follows: "What are the relationships between Turkish teachers' basic technology competency, their attitude towards computer assisted education and their information technologies operation level in Turkish lessons?"

The research has discussed with the sub-problems below:

1) How is Turkish teachers' basic technology competency, their attitude towards computer assisted education and their information technologies operation level in Turkish lessons?

2) Do Turkish teachers' basic technology competency, their attitude towards computer assisted education and their level of using information technologies in Turkish lessons show remarkable differences considering gender, teaching experience, and education level?

3) Are there meaningful relationships between their technology competency, their attitude towards computer assisted education and their information technologies operation level in Turkish lessons? 


\section{Method}

\subsection{Research Design}

This research is designed with relational screening model which is one of the general screening models. "Relational screening models aim at determining the presence of change and/or the degree of this change between two or more variables" (Karasar, 2009, p. 81).

The implementation method of the research is face to face interviews with teachers. With the personal participation of the researcher, the implementation was carried out through the appointments made with school managements. Answering the questionnaires was completed in 10-15 minutes. The research was done from May 16 to June 17 in 2016.

\subsection{Population and Sampling}

Turkish language teachers who worked in state schools of Bartin comprised the environment of this research. Reaching all the teachers was the intention of this study. That is why no samples were received. All the Turkish teachers in secondary schools -29 in the center of Bartin, 5 in Amasra, 4 in Kurucasile, 6 in Ulus- were reached. The entire population comprised 87 Turkish teachers working in 44 secondary schools. One teacher did not want to participate in the study, and one another teacher was on leave. The study was carried out with the total number of 85 teachers who worked in Bartin province, except the two teachers mentioned above. The distributions of the participants in the research according to the independent variables are illustrated in Table 1.

Table 1. The distribution of the participants according to the independent variables

\begin{tabular}{llcc}
\hline Independent Variables & & Frequency & Percentage \\
\hline \multirow{2}{*}{ Gender } & Female & 46 & 54.1 \\
& Male & 39 & 45.9 \\
& $1-5$ & 24 & 28.2 \\
Teaching experience & $6-10$ & 15 & 17.6 \\
& $11-15$ & 23 & 27.1 \\
& $16-20$ & 16 & 18.8 \\
& $21+$ & 7 & 8.2 \\
Educational level & Undergraduate & 2 & 2.4 \\
& Graduate & 79 & 92.9 \\
& Postgraduate & 4 & 4.7 \\
& TOTAL & 85 & 100 \\
\hline
\end{tabular}

As seen in Table 1, 54.1\% of the participants are female, $45.9 \%$ of them are male. Teachers serving a duty of 20 years or less regarding the teaching experience and considering education level, the number of graduate teachers being the majority is noteworthy.

\subsection{Data Collection Means}

Three instruments were used in the research to collect the data. These are "Basic Technology Competency Scale for Educators" originally developed by Flowers and Algozzine (2000) and adapted to Turkish by Tekinarslan (2008), "Attitude Scale toward Making Computer Supported Education" developed by Arslan (2006), and "The Questionnaire of Using Education Technologies" taken from the "Social Learning Project of Ohio University" and adapted to Turkish Education system by İşsman (2002).

"Basic Technology Competency Scale for Educators" consists of nine dimensions. These are; "basic computer using skills, installation, maintenance and troubleshooting, Word processing, spreadsheet, database, the internet network, telecommunication, multimedia communications, social, legal and ethical issues. Three more items have been added to the original scale consisting of 45 items by Tekinarslan (2008) regarding daily issues, and the latest technological advances. As a result, the total number of items on the scale is 48 . The reliability coefficient of the nine dimensions on the scale adapted to Turkish are $\alpha=.91, .95, .92, .92, .88, .88, .88, .90, .61$, and for the whole scale, it is determined as $\alpha=.95$. The type of the scale is four-point Likert. The answers are respectively "Insufficient (1), A bit sufficient (2), Sufficient (3), and Very Sufficient (4)" (Tekinarslan, 2008). In this research, the subscales reliability coefficients were respectively $\alpha=94, .92, .91, .90, .97, .90, .75, .93, .94$ and the whole scale was calculated as $\alpha=.96$.

"Attitude Scale toward Making Computer Supported Education" is a five-point Likert-type scale consisting of 20 
items 10 of which are positive and 10 of which are negative. The Cronbach-Alpha reliability coefficient of the instrument is .93. The scale is one-dimensional and the total variance explained is $33 \%$. The reliability coefficient of this scale is calculated as 0.93 in this research. The range of 20-100 points could be achieved from the instrument.. The score between 20 and 46 is low, the score between 47 and 74 is moderate, and the score between 75 and 100 is high, and the latest one states the high-level of attitude.

To determine teachers' technology operation level in Turkish lessons, "The Questionnaire of Using Education Technologies" taken from "Social Learning Project of Ohio University" and adapted to Turkish Education System by İşman (2002) was considered as a basis; however, some changes were made. The original questionnaire consists of 6 parts. These parts are "technologies with flat structure, computer technologies, audio-visual technologies, internet-based technologies, teaching-learning methods, and theoretical dimension." In this research, technologies with the flat structure, teaching-learning methods, and theoretical dimension were not used. From "computer technologies, audio-visual technologies, internet-based technologies," the technologies which are suitable to use in teaching Turkish and the ones which have not lost their topicality were chosen. New technologies which do not exist in the original questionnaire have been added to the questionnaire. In its latest form, the dimensions, the content of the dimensions, and reliability coefficients of the questionnaire are as follows:

1) Computer Technologies: Word, power point, excel, scanner, digital camera, data show, printer, computer, projector, paint, flash, BS player, Windows media player, video cut, sound installation, smart board, CD-ROM, flash drive. 17 items in total. Alfa .89

2) Audio-visual Technologies: television-radio, video, CD, film, video camera, overhead projector, DVD. Seven elements in total. Alfa .73

3) Internet-Based Technologies: the internet, www pages, internet camera, social media, search engines. Five items in total. Alfa .77

The questionnaire consists of 29 items. The type of questionnaire is four-point Likert. The question, "How often do you use these technologies in Turkish lessons?" has been asked to Turkish teachers. The answers are listed as "Have never used (1), rarely used (2), often used (3), used very often (4)".

\subsection{Data Analysis Techniques}

Turkish teachers' information technology competency, attitude towards computer-assisted education and information technologies operation level in Turkish lessons were illustrated by descriptive statistics analysis.

The gender differences in Turkish teachers' technology competency, their attitude towards computer-assisted education and their information technologies operation level in Turkish lessons were determined using the analysis of Independent Samples t-test and the differences according to teaching experience, and education level were determined with the analysis technique of one way ANOVA.

The relations between the dependent variables of the research have been examined by Pearson correlation analysis. "While researching correlation type associations, whether variants change together or not and if there is a change, how this change has happened is tried to be understood" (Karasar, 2009, p. 82). Correlation levels were interpreted regarding the intervals determined by Cohen (1988). According to this, the value in the range of.10-.29 is described as weak, .30-.49 as moderate and .50- 1.00 as strong.

\section{Results}

\subsection{First Sub-Problem}

Turkish teachers' information and communication technologies competency, attitude towards computer assisted education and information technologies operation level in Turkish lessons are illustrated in Table 2, 3 and 4. 
Table 2. Basic technology competency levels of Turkish teachers

\begin{tabular}{|c|c|c|c|c|c|c|}
\hline \multirow{2}{*}{ Subscales } & \multirow{2}{*}{$\mathrm{n}$} & \multirow{2}{*}{$\bar{X}$} & \multirow{2}{*}{ ss } & \multicolumn{3}{|c|}{ Interval } \\
\hline & & & & Low & Medium & High \\
\hline Basic computer operation skills & 85 & 25.82 & 3.33 & $7-14$ & $14.01-21$ & $21.01-28$ \\
\hline $\begin{array}{l}\text { Setup, maintenance, and troubleshooting of } \\
\text { equipment }\end{array}$ & 85 & 18.20 & 4.21 & $6-12$ & $12.01-18$ & $18.01-24$ \\
\hline Word processing & 85 & 17.87 & 2.49 & $5-10$ & $10.01-15$ & $15.01-20$ \\
\hline Spreadsheets & 85 & 12.31 & 3.55 & $5-10$ & $10.01-15$ & $15.01-20$ \\
\hline Database & 85 & 10.03 & 4.43 & $5-10$ & $10.01-15$ & $15.01-20$ \\
\hline Networking & 85 & 16.37 & 3.19 & $5-10$ & $10.01-15$ & $15.01-20$ \\
\hline Telecommunication & 85 & 14.69 & 3.04 & $5-10$ & $10.01-15$ & $15.01-20$ \\
\hline Media communication & 85 & 15.78 & 3.97 & $5-10$ & $10.01-15$ & $15.01-20$ \\
\hline Social, legal, and ethical issues & 85 & 12.63 & 4.25 & $5-10$ & $10.01-15$ & $15.01-20$ \\
\hline Total scale & 85 & 143.74 & 22.54 & $48-96$ & $96.01-144$ & $144.01-192$ \\
\hline
\end{tabular}

As seen in Table 2, Turkish teachers' basic technology competencies are high on the subscales "Basic computer operation skills, setup, maintenance, troubleshooting, Word processing, networking, media communication." However, their competencies on the subscales "spreadsheets, database, telecommunication and social, legal and ethical issues" are medium. Considering the whole of the scale, the technology competency of Turkish teachers is medium.

Table 3. Turkish teacher's attitude towards computer-assisted education

\begin{tabular}{lcc}
\hline Level & $\mathrm{f}$ & $\%$ \\
\hline Low (20-46) & 0 & 0 \\
Medium (47-74) & 15 & 17.6 \\
High (75-100) & 70 & 82.4 \\
\hline Total & 85 & 100 \\
\hline
\end{tabular}

When Turkish teachers' attitude towards computer-assisted education was examined, it was seen that 70 teachers (82.4\%) had a high-level attitude, 15 teachers had a medium-level attitude. There had been no low attitude noticed. The total score average of the whole scale has been calculated as 81.85 . When this score is divided into the total number of the items on the scale, the average is 4.09. Also, these scores indicate that Turkish teachers' attitude towards computer-assisted education is high.

Table 4. Turkish teachers' technology operation level in lessons

\begin{tabular}{|c|c|c|c|c|c|c|}
\hline \multirow{2}{*}{ Subscales } & \multirow{2}{*}{$\mathrm{n}$} & \multirow{2}{*}{$\bar{X}$} & \multirow{2}{*}{ Ss } & \multicolumn{3}{|c|}{ Interval } \\
\hline & & & & Low & Medium & High \\
\hline Internet-based technologies & 85 & 11.87 & 3.459 & $5-10$ & $10.01-15$ & $15.01-20$ \\
\hline Audio-visual technologies & 85 & 14.00 & 3.508 & $7-14$ & $14.01-21$ & 21.01-28 \\
\hline Computer technologies & 85 & 41.25 & 9.368 & $17-34$ & $34.01-51$ & $51.01-68$ \\
\hline Total scale & 85 & 67.12 & 14.11 & $29-58$ & $58.01-87$ & $87.01-116$ \\
\hline
\end{tabular}

As seen in Table 4, Turkish teachers' technology operation levels in lessons are medium in the subscale of internet-based technologies, computer technologies, and total scale. However, audio-visual technology using level is low.

\subsection{Second Sub-Problem}

The results of the analysis conducted to determine whether Turkish teachers' basic technology competency, attitude towards computer-assisted education and technology operation level indicate meaningful differences according to gender, teaching experience and education level or not are represented in Table 5, 6 and 7 . 
Table 5. The difference in Turkish teachers' basic technology competency, operation level and attitude towards computer-assisted education in Turkish lessons according to gender

\begin{tabular}{|c|c|c|c|c|c|c|c|}
\hline & Gender & $\mathrm{N}$ & $\bar{X}$ & $\mathrm{~S}$ & sd & $\mathrm{t}$ & $\mathrm{p}$ \\
\hline \multirow[b]{2}{*}{ Basic technology competency } & Female & 46 & 140.17 & 21.37 & \multirow{2}{*}{83} & \multirow{2}{*}{1.59} & \multirow{2}{*}{.114} \\
\hline & Male & 39 & 147.94 & 23.43 & & & \\
\hline \multirow{2}{*}{ Attitude towards computer-assisted education } & Female & 46 & 81.71 & 10.73 & \multirow{2}{*}{83} & \multirow{2}{*}{.130} & \multirow{2}{*}{.897} \\
\hline & Male & 39 & 82.02 & 11.15 & & & \\
\hline \multirow{2}{*}{ Technology operation level in Turkish lessons } & Female & 46 & 66.73 & 13.37 & \multirow{2}{*}{83} & \multirow{2}{*}{.275} & \multirow{2}{*}{.784} \\
\hline & Male & 39 & 67.58 & 15.10 & & & \\
\hline
\end{tabular}

As seen in Table 5, Turkish teachers' information and communication technologies competency, attitude towards computer-assisted education and technology operation level in Turkish lessons do not indicate statistically significant differences based on their gender. Especially, although male teachers acquire higher average scores than then female teachers considering technology competency, the difference is not significant.

Table 6. The difference in Turkish teachers' basic technology competency, attitude towards computer-assisted education and technology operation level in Turkish lessons according to teaching experience

\begin{tabular}{lcccccc}
\hline & Variance Source & $\begin{array}{c}\text { Sum of } \\
\text { Squares }\end{array}$ & sd & $\begin{array}{c}\text { Mean of } \\
\text { Squares }\end{array}$ & F & p \\
\hline \multirow{3}{*}{ Basic technology competency } & Between groups & 1104.26 & 4 & 276.06 & .531 & .713 \\
& Within group & 41608.04 & 80 & 520.10 & & \\
& Total & 42712.30 & 84 & & & \\
Attitude towards computer assisted education & Between groups & 516.90 & 4 & 129.22 & 1.100 & .362 \\
& Within group & 9397.40 & 80 & 117.46 & & \\
& Total & 9914.30 & 84 & & & \\
& Between groups & 737.45 & 4 & 184.36 & & \\
Technology operation level in Turkish lessons & Within group & 16002.12 & 80 & 200.02 & .922 & .456 \\
& Total & 16739.57 & 84 & & & \\
\hline
\end{tabular}

As seen in Table 6, Turkish teachers' information and communication technologies competency, attitude towards computer-assisted education and technology operation level in Turkish lessons do not indicate a statistically significant difference based on their teaching experience.

Table 7. The difference in Turkish teachers' basic technology competency, attitude towards computer-assisted education and information technology operation level in Turkish lessons according to their education level

\begin{tabular}{lcccccc}
\hline & Variance Source & $\begin{array}{c}\text { Sum of } \\
\text { Squares }\end{array}$ & sd & $\begin{array}{c}\text { Mean of } \\
\text { Squares }\end{array}$ & F & p \\
\hline \multirow{3}{*}{ Basic technology competency } & Between groups & 669.47 & 2 & 334.73 & .653 & .523 \\
& Within group & 42042.83 & 82 & 512.71 & & \\
& Total & 42712.30 & 84 & & & \\
Attitude towards computer assisted education & Between groups & 381.96 & 2 & 190.98 & 1.643 & .200 \\
& Within group & 9532.34 & 82 & 116.24 & & \\
& Total & 9914.30 & 84 & & & \\
Technology operation level in Turkish lessons & Between groups & 909.15 & 2 & 454.57 & 2.355 & .101 \\
& Within group & 15830.42 & 82 & 193.05 & & \\
& Total & 16739.57 & 84 & & & \\
\hline
\end{tabular}

As seen in Table 7, Turkish teachers' information and communication technologies competency, attitude towards computer-assisted education and technology operation level in Turkish lessons do not indicate statistically significant differences based on their education level.

\subsection{Third Sub-Problem}

The relationships between Turkish teachers' basic technology competency, attitude towards computer-assisted 
education and technology operation level in Turkish lessons are represented in Table 8.

Table 8. The relations between Turkish teachers' basic technology competency, attitude towards computer-assisted education and technology operation level in Turkish lessons

\begin{tabular}{lcccc}
\hline & & 1 & 2 & 3 \\
\hline 1. Technology operation level in Turkish lessons & $\mathrm{r}$ & 1 & $.504(* *)$ & $.345\left(^{* *}\right)$ \\
& $\mathrm{p}$ & & .000 & .001 \\
& $\mathrm{n}$ & 85 & 85 & 85 \\
\hline 2. Attitude towards computer assisted education & $\mathrm{r}$ & $.504(* *)$ & 1 & $.452(* *)$ \\
& $\mathrm{p}$ & .000 & & .000 \\
& $\mathrm{n}$ & 85 & 85 & 85 \\
\hline 3. Basic technology competency & $\mathrm{r}$ & $.345(* *)$ & $.452(* *)$ & 1 \\
& $\mathrm{p}$ & .001 & .000 & \\
& $\mathrm{n}$ & 85 & 85 & 85 \\
\hline
\end{tabular}

$* * \mathrm{p}<.01$

There is a high-level relationship $(\mathrm{r}=.504)$ between Turkish teachers' technology operation level in Turkish lessons and attitude towards computer-assisted education. There is a medium-level relationship $(\mathrm{r}=.345)$ between technology operation level in Turkish lessons and technology competency. There is a medium-level $(\mathrm{r}=.452)$ relationship between technology competency level and the attitude towards computer-assisted education.

\section{Discussion}

This research was done to determine Turkish teachers' basic technology competencies, attitude towards computer- assisted education and technology operation level in Turkish lessons and the relationships between them. Results are discussed depending on the sub-problems below.

\subsection{Discussion on First Sub-Problem}

At the end of the research, Turkish teachers' information technologies competency was calculated as high in "Basic Computer Operation Skills, Setup, Maintenance and Troubleshooting of Equipment, Word Processing, Networking, Media Communication"; and medium in "Spreadsheets, Database, Telecommunication and Social, Legal and Ethical Issues". It can be said that the most necessary computer skills for professional works improved. "Basic Computer Operation Skills" was the dimension with the highest average. This result is parallel to the findings of the previous studies (Güneş, Gökçek, \& Bacanak, 2010; Menzi, Çalışkan, \& Çetin, 2012; Sa'ari, Luan, \& Roslan, 2005).

It was determined that "Database Competency" was a dimension that Turkish teachers had the lowest average. The same result is seen in the studies conducted to the teachers of different branches (Seferoğlu, Akbiyık, and Bulut, 2008; Güneş, Gökçek, and Bacanak, 2010; Turel, 2014) and with Turkish prospective teachers (Özbay and Çelik, 2013). Little use of database by teachers can be explained by their not needing the database.

The scale conducted to Turkish teachers in this research has previously been used by Güneş, Gökçek, and Bacanak (2010) with teachers of different branches; also by Menzi, Çalışkan, and Çetin (2012) with prospective teachers and by Ulaş and Ozan (2010) with classroom teachers. The average scores of this study are higher than the scores reported in the previous research mentioned above. This result indicates an argument opposite to the belief that Turkish teachers are away from technology. It is also important as it indicated that teachers' technology competency can increase in time with computer courses and FATIH Project.

Considering their attitude towards computer-assisted education, $82.4 \%$ of Turkish teachers have a high-level, and $17.6 \%$ of them have a medium-level attitude. Low-level of attitude has not been met. With the same scale, Turkish teachers' attitude towards computer-assisted education was examined by Kahraman (2013), and prospective Turkish teachers' attitude towards computer-assisted education was investigated by Şahin and Akçay (2011), and it was found out that both teachers and prospective teachers had a medium-level attitude. The average score $(\bar{X}=4.09)$ obtained in this research indicates that Turkish teachers have a very high-level of attitude. As a result of technology is occupying more space in daily life and in the educational environment day by day and teachers' becoming more competent in information technologies operation, that teachers' attitude towards computer-assisted education increases has been observed in the studies done up to the present time. Positive attitude towards technology is seen as a necessary condition to use information technologies effectively in the 
lessons (Woodrow, 1992, cited in Christensen, 2002, p. 411). Due to this, the result of this research emphasizes that Turkish teachers are ready affectively and intellectually to use technology in their lessons.

Similar results are also observed in the studies conducted to prospective Turkish teachers. Research indicate that in general prospective Turkish teachers develop positive attitude towards using technology in education (Dargut \& Çelik, 2014; Kahraman, 2013; Şahin \& Akçay, 2011), self-confidence in using education technologies at an adequate level (Eyüp, 2012). Moreover, they believe that using education technologies in teaching Turkish will contribute to reaching the objectives of the lesson (Atl1 et al., 2007). Research findings indicate that teachers' getting together and exchanging ideas provide an opportunity for development considering technology integration (Gorder, 2008; Papanastasiou \& Angeli, 2008). Owing to this, it could be considered that young teachers provide motivation to experienced teachers about using technology in lessons.

Turkish teachers' technology operation level in Turkish lessons was addressed by the dimensions of "internet-based technologies, audio-visual technologies, and computer technologies." It was determined that Turkish teachers used technology in their classes in the dimensions of internet based technologies, and computer technologies at the medium, but in the dimension of audio-visual technologies at the low-level.

Although Turkish teachers develop a high-level of technology competency in a lot of dimensions and attitude towards computer-assisted education, it is remarkable that they use a medium-level of technology in Turkish lessons. In the schools where the present research was performed, it was observed that even though the installation of smart boards was completed, the internet connection was not provided. This situation could be given as a reason for a medium-level technology using. Papanastasiou and Angeli (2008, p. 74), state that technological infrastructure describes $6.67 \%$ of technology operation variance. Lots of other elements different from infrastructure can be expressed to influence technology operation. Adopting student-centred education in the lessons (Rakes et al., 2006; Ryba and Brown, 2000), teachers' technological pedagogical content knowledge (Sahin et al., 2013), beliefs considering technology operation in lessons (Christensen, 2002; Mumtaz, 2000; Papanastasiou \& Angeli, 2008), teachers' being open to new ideas (Kaya \& Koçak-Usluel, 2011) can be described as the elements affecting technology operation in lessons.

The teachers involved in the present research attended computer courses. They were thought how to use a computer in these courses, but how to transfer the learned skills to lessons remains uncertain. Having technological pedagogical content knowledge described as having the skill of presenting a particular subject in the most suitable way using technology (Keating \& Evans, 2001) is a factor that affect technology operation in lessons (Mishra \& Koehler, 2006; Tella et al., 2007).

This research is limited with Turkish teachers' basic technology competency and attitude towards technology-assisted education. Therefore, other reasons affecting Turkish teachers' technology operation in lessons might be a situation that needs to be examined.

\subsection{Comments on Second Sub-Problem}

It was found that Turkish teachers' basic technology competency, attitude towards computer-assisted education, information technology operation level in Turkish lessons did not indicate significant differences based on gender, teaching experience and education level. In the field, there have been studies which indicate that basic technology competency differs depending on gender as men are more competent than women (Bilici \& Güler, 2016; Kay, 2006; Menzi \& Çalışkan, 2012; Tekinarslan, 2008). However, in this study no difference has been found related to gender. This result is compatible with the researches done by Adalier (2012), Gorder (2008), Güven (2015), Güneş, Gökçek, \& Bacanak (2010), Gökçek et al. (2013). It could be expressed that professional computer operation has become compulsory for teachers, in today's world where communication spreads quickly using social media, women's technology competency is developed as much as men's.

There have been studies whose findings indicate that considering teaching experience, young teachers' technology competency is higher than the veterans (Güneş et al., 2010; Gökçek et al., 2013). However, in this research, it was observed that teaching experience caused no difference for technology competency. This result is compatible with the research done by Gorder (2008) and Güven (2015).

The finding that Turkish teachers' attitude towards technology operation in lessons do not indicate significant differences is compatible with the findings of other research in this field. Kahraman (2013), Karasakaloğlu, Saracaloğlu, and Uça (2011), Eyüp (2012), and Şahin and Akçay (2011) found that no differences between genders.

In the studies' findings regarding the relationship between technology operation in lessons and gender, as there are researchers who reach the result that men use technology in lessons more than women (İşman, 2002; Ulaş \& 
Ozan, 2010; Wozney et al., 2006), there are research indicate that women use technology more (Buabeng-Andoh, 2012) or more willing to use (Wu et al., 2016) it in lessons as well. In this research, it has been stated that technology operations in lessons do not indicate any difference depending on gender. This result is compatible with the research done by Gorder (2008), and Yllmaz-Eroldoğan (2007). One of the important factors that determine technology operation is the education given to teachers (Christensen, 2002). As a result, it could be explained that giving in-service training to teachers is effective in addition to the increase in teachers' technology competency, wider use of technology in daily and professional life.

There are studies which mention that teaching experience is a factor that affects information technologies operation in lessons ( Wong, and Li, 2008) and young teachers use technology more in lessons (Gegeoğlu, 2014; Işman, 2002; Kocaoğlu, 2013; Yılmaz-Eroldoğan, 2007). As opposed to these research, there are the ones which state that experienced teachers use technologies more often in their lessons (Lau \& Sim, 2008; Ulaş \& Ozan, 2010). However, in this research, no significant difference has been found between teaching experience and technology operation in lessons. This result is parallel to the finding of the research found by Gorder (2008), and Granger et al. (2002). Having information and communication technologies in classes motivate teachers to use these more in their lessons (Tella et al., 2007). Due to this, it can be said that completing the installation of smart boards in secondary schools in Bartin has a share in the result.

In the field, there are studies that mention the frequency of technology operation in lessons increases as the education level of teachers' increases (İşman, 2002; Yılmaz-Eroldoğan, 2007). At the same time, there are also research mentions that education level makes no difference considering technology operation in lessons (Gegeoğlu, 2014; Gorder, 2008; Ulaş \& Ozan, 2010). In this research, it is also found that technology operation indicate no meaningful difference regarding education level. However, it is believed that $92.9 \%$ of participants' being graduates might have affected the result.

\subsection{Comments on Third Sub-Problem}

Between Turkish teachers' technology operation level in lessons and their attitudes towards computer-assisted education in lessons, there was a high-level $(\mathrm{r}=.504)$ relationship. Moreover, between their technology using level in lessons and technology competency, a medium $(r=.345)$ relationship was found. This result indicates that the attitude towards computer-assisted education is a more powerful factor than technology competency.

A medium $(\mathrm{r}=.452)$ relationship was found between technology competency level and attitude towards computer-assisted education. A similar result was found in a research done by Lau and Sim (2008). In the research mentioned, the correlation coefficient between competency level and the attitude towards computer-assisted education was .507. Shin (2015) also found a medium correlation between teachers' use of ICT in practice and attitude toward computers in education with together technology competence. As a result, it could be said that the more teachers' technology competency increases, the more their attitude towards computer-assisted education will increase, and this will lead to using more technology in lessons.

\section{Suggestions}

The suggestions developed within the frame of the research findings are below:

1) Technological infrastructure of schools should be improved.

2) Materials and software about the area should be developed and offered to Turkish teachers for use.

3) Courses on how to use technology in lessons should be designed for Turkish teachers.

4) Factors that affect Turkish teachers' technology operation negatively should be examined.

\section{Acknowledgements}

I declare that I have no significant competing financial, professional, or personal interests that might have influenced the performance or presentation of the work described in this manuscript.

\section{References}

Adalier, A. (2012). Turkish and English language teacher candidates' perceived computer self-efficacy and attitudes toward computer. The Turkish Online Journal of Educational Technology, 11(1), 192-201.

Allport, G.W. (1935). Attitudes. In C. Murchison (Ed.), Handbook of social psychology. Worcester, Mass: Clark University Press.

Arslan, A. (2006). The attitude scale toward making computer supported education. Yuzuncu Yil University Journal of Education, 3(2), 24-33. 
Arslan, A. (2008). Affection of the Turkish instruction in support of computer method to the attitudes of the students of Turkish lesson. e-Journal of New World Sciences Academy, 4(2), 665-677.

Atlı, Ş., Aksüt, M., Atar, G., \& Yıldız, N. (2007). Opinions of student teachers upon use of information technology. Akademik Bilişim'07-IX. Academic Computing Conference Papers, Dumlupınar University, Kütahya (pp. 737-741).

Bilici, S., \& Güler, Ç. (2016). Investigation of teachers' TPACK levels with respect to use of instructional technologies. Elementary Education Online, 15(3), 898-921. https://doi.org/10.17051/io.2016.05210

Buabeng-Andoh, C. (2012). Factors influencing teachers' adoption and integration of information and communication technology into teaching: A review of the literature. International Journal of Education and Development using Information and Communication Technology, 8(1), 136-155.

Büyüköztürk, Ş. (2011). Sosyal bilimler için veri analizi el kitabı (14th ed.). Ankara: Pegem Akademi.

Christensen, R. (2002). Effects of technology integration education on the attitudes of teachers and students. Journal of Research on Technology in Education, 34, 411-433. https://doi.org/10.1080/15391523.2002.10782359

Cohen, J. (1988). Statistical power analysis for the behavioral sciences (2nd ed.). Hillsdale, NJ: Lawrence Erlbaum Associates.

Dargut, T., \& Çelik, G. (2014). Pre-Service Turkish language teachers' attitudes and thoughts toward use of technology in education. Journal of Mother Tongue Education, 2(2), 28-41.

Durukan, E. (2011). The effect of computer-assisted grammar teaching at primary school 6th grade on success and attitude (Unpublished Ph.D. thesis). Atatürk University Institute of Educational Sciences, Erzurum.

Eyüp, B. (2012). Turkish teacher candidates' self-confidence about use of instructional technologies. Adiyaman University Journal of Social Sciences, 5(9), 77-87. https://doi.org/10.14520/adyusbd.280

Flowers, C. P., \& Algozzine, R. F. (2000). Development and validation of scores on the basic technology competencies for educators inventory. Educational and Psychological Measurement, 60(3). https://doi.org/10.1177/00131640021970628

Gorder, L. M. (2008). A study of teacher perceptions of instructional technology integration in the classroom. Delta Pi Epsilon Journal, 50(2), 63-76.

Gökçek, T., Güneş, G., \& Gençtürk, E. (2013). Evaluation of primary school teachers' technological self-efficacy. International Online Journal of Educational Sciences, 5(1), 42-51

Granger, C. A., Morbey, M. L., Lotherington, H., Owston, R. D., \& Wideman, H. H. (2002). Factors contributing to teachers' successful implementation of IT. Journal of Computer Assisted Learning, 8, 480-488. https://doi.org/10.1046/j.0266-4909.2002.00259.doc.x

Güneş, G., Gökçek, T., \& Bacanak, A. (2010). How do teachers evaluate themselves in terms of technological competencies? Procedia Social and Behavioral Sciences, 9, 1266-1271. https://doi.org/10.1016/j.sbspro.2010.12.318

Güven, A. Z. (2015). Qualifications of Turkish teachers' in using educational technology. International Journal of Language Academy, 3(4), 99-114. https://doi.org/10.17051/io.2016.05210

İşman, A. (2002). Sakarya ili öğretmenlerinin eğitim teknolojileri yönündeki yeterlilikleri. The Turkish Online Journal of Educational Technology, 1(1), 72-91.

Kahraman, E. (2013). The relationship between Turkish teachers' attitudes towards computer education and technology (Unpublished master's thesis). Niğde University Institute of Educational Sciences, Niğde.

Kalaycı, Ş. (Ed.). (2010). SPSS uygulamalı çok değisskenli istatistik teknikleri. Ankara: Asil Yayın Dağıtım Ltd. Şti.

Kalkınma Bakanlığı. (2013). Onuncu Kalkınma Planı. Ankara. Retrieved from http://www.kalkinma.gov.tr/Lists/Kalknma\%20Planlar/Attachments/12/Onuncu\%20Kalk\%C4\%B1nma\%20 Plan\%C4\%B1.pdf

Karasakaloğlu, N., Saracaloğlu, S., \& Uça, S. (2011, Aralık). Investigation of Turkish teachers' attitudes towards technology and levels of using information technologies. Mersin University Journal of Education, 7(2), 26-36. 
Karasar, N. (2009). Bilimsel araştırma yöntemi. Ankara: Nobel Yayın Dağıtım.

Katranc1, M., \& Uygun, M. (2013). Classroom teacher's perspectives about using technology in Turkish lessons. Adiyaman University Journal of Institute of Social Sciences Special Issue of Education and Teaching of Turkish, 6(11), 773-797. https://doi.org/10.14520/adyusbd.460

Kay, R. (2006). Addressing gender differences in computer ability, attitudes and use: The laptop effect. Journal of Educational Computing Research, 34(2), 187-211. https://doi.org/10.2190/9BLQ-883Y-XQMA-FCAH

Kaya, G., \& Koçak-Usluel, Y. (2011). Content analysis of factors affecting ICT integration in teaching learning process. Buca Ĕgitim Fakültesi Dergisi Befjournal, 31, 48-67.

Keating, T., \& Evans, E. (2001). Three computers in the back of the classroom: preservice teachers' conceptions of technology integration. In J. Price et al. (Eds.), Proceedings of Society forInformation Technology \& Teacher Education International Conference 2001 (pp. 1671-1676). Chesapeake, VA: AACE. Retrieved from http://www.editlib.org/p/17023

Koçak-Usluel, Y., Kuşkaya-Mumcu, F., \& Demiraslan, Y. (2007). ICT in the learning-teaching process: Teachers' views on the integration and obstacles. Hacettepe University Journal of Education, 32, 164-178.

MEB Board. (2008). Special Area Competency of Turkish Teachers. Retrieved from http://otmg.meb.gov.tr/belgeler/ogretmen_yeterlikleri_kitabi/\%C3\%96\%C4\%9Fretmen_Yeterlikleri_Kitab $\% \mathrm{C} 4 \% \mathrm{~B} 1 \_\mathrm{t} \% \mathrm{C} 3 \% \mathrm{BCrk} \% \mathrm{C} 3 \% \mathrm{~A} 7 \mathrm{e} \_\% \mathrm{C} 3 \% \mathrm{~B} 6 \% \mathrm{C} 4 \% 9$ Fretmeni_\%C3\%B6zel_alan_yeterlikleri_ilk\%C3\% B6\%C4\%9Fretim_par\%C3\%A7a_4.pdf

Menzi, N., \& Çalıskan, E. (2012). Examination of the competencies of pre-service teachers in terms of some variables. Anadolu Journal of Educational Sciences International, 2(1), 1-18.

Mishra, P., \& Koehler, M. J. (2006). Technological pedagogical content knowledge: A framework for teacher knowledge. Teachers College Record, 108(6), 1017-1054. https://doi.org/10.1111/j.1467-9620.2006.00684.x

Mumtaz, S. (2000). Factors affecting teachers' use of information and technology: A review of the literature. Journal of Information Technology for Teacher Education, 9(3), 319-341. https://doi.org/10.1080/14759390000200096

Oval1, T. (2011). The effect of computer-aided instruction in the eighth-grade elementary Turkish course to the ability of comprehension (Unpublished master's thesis). Sakarya University Institute of Educational Sciences, Sakarya.

Özbay, M., \& Çelik, M. E. (2013). The evaluation of opinions of Turkish candidate teachers on proficiency in the use of computers. Journal of Mother Tongue Education, 1(1), 107-115.

Papanastasiou, E. C., \& Angeli, C. (2008). Evaluating the use of ICT in education: Psychometric properties of the survey of factors affecting teachers teaching with technology $\left(\mathrm{SFA}-\mathrm{T}^{3}\right)$. Educational Technology \& Society, 11(1), 69-86.

Peralta, H., \& Costa, F. A. (2007). Teachers' competence and confidence regarding the use of ICT. Educational Sciences Journal, 3, 75-84.

Rakes, G. C., Fields, V. S., \& Cox, K. E. (2006). The influence of teachers' technology use on instructional practices. Journal of Research on Technology in Education, 38(4), 409. https://doi.org/10.1080/15391523.2006.10782467

Ryba, K., \& Brown, M. E. (2000). How proficient IT teachers integrate computers into the curriculum. Journal of Computing in Teacher Education, 16, 6-11.

Sa'ari, J. R., Luan, W. S., \& Roslan, S. (2005). Attitudes and perceived information technology competency among teachers. Malaysian Online Journal of Instructional Technology (MOJIT), 2(3), 70-77.

Sahin, I., Celik, I., Akturk, A. O., \& Aydin, M. (2103). Analysis of relationships between technological pedagogical content knowledge and educational internet use. Journal of Digital Learning in Teacher Education, 29(4), 110-117. http://dx.doi.org/10.1080/21532974.2013.10784714

Seferoğlu, S. S., Akbiyık, C., \& Bulut, M. (2008). Elementary school teachers' and teacher candidates” opinions about computer use in learning/teaching process, Hacettepe University Journal of Education, 35, 273-283.

Shin, V. S. (2015). Teachers' use of technology and its influencing factors in Korean elementary schools. Technology, Pedagogy and Education, 24(4), 461-476. https://doi.org/10.1080/1475939X.2014.915229

Şahin, A., \& Akçay, A. (2011). An analysis of Turkish language teacher candidates' attitudes towards 
computer-assisted education. TurkishStudies-International Periodical For The Languages, Literature and History of Turkish or Turkic, 6(2), 909-918. https://doi.org/10.7827/TurkishStudies.2288

Tekinarslan, E. (2008). A validity and reliability study of the basic technology competencies scale for educators. Electronic Journal of Social Sciences, 7(26), 186-205.

Tella, A., Tella, A., Toyobo, O. M., Adika, L. O., \& Adeyinka, A. A. (2007). An assessment of secondary school teachers uses of ICT's: Implications for further development of ICT's use in Nigerian secondary schools. The Turkish Online Journal of Educational Technology, 6(3), 5-17.

Turel, V. (2014). Teachers' computer self-efficacy and their use of educational technology. Turkish Online Journal of Distance Education-TOJDE, 15(4), 130-149. https://doi.org/10.17718/tojde.81990

Ulaş, A. H., \& Ozan, C. (2010). The qualification level of primary school teachers' use of educational technology. Atatürk University Journal of Social Sciences, 14(1), 63-84.

Wong, E. M. L., \& Li, S. C. (2008). Framing ICT implementation in a context of educational change: A multilevel analysis. School effectiveness and school improvement, 19(1), 99-120. https://doi.org/10.1080/09243450801896809

Wozney, L., Venkatesh, V., \& Abrami, P. C. (2006). Implementing computer technologies: Teachers' perceptions and practices. Journal of Technology and Teacher Education, 14(1), 173-207.

Yıldırım, A., \& Şimşek. H. (2013). Sosyal bilimlerde nitel araştırma yöntemleri. Ankara: Seçkin Yayıncılık.

Yılmaz-Eroldoğan, A. (2007). An investigation on the usage of instructional technologies by the subject teachers according to some variables at the second grade of the primary schools (Unpublished master's thesis). Çukurova University Institute of Social Sciences, Adana.

Zobar, Y. (2010). Effect of computer-aided instruction in the elementary third-grade students achievement and attitudes of the course (Unpublished master's thesis). Sakarya University Institute of Social Sciences, Sakarya.

\section{Copyrights}

Copyright for this article is retained by the author(s), with first publication rights granted to the journal.

This is an open-access article distributed under the terms and conditions of the Creative Commons Attribution license (http://creativecommons.org/licenses/by/4.0/). 